\title{
Embelin-induced MCF-7 breast cancer cell apoptosis and blockade of MCF-7 cells in the G2/M phase via the mitochondrial pathway
}

\author{
YANG LI $^{1 *}$, DALEI LI ${ }^{2 *}$, SHENGGUANG YUAN ${ }^{3}$, ZHENRAN WANG $^{4}$, FANG TANG $^{4}$, \\ RONGRONG NIE ${ }^{4}$, JUN WENG ${ }^{3}$, LINA MA $^{2}$ and BO TANG ${ }^{3}$ \\ ${ }^{1}$ Department of Medical Oncology, Affiliated Hospital of Guilin Medical University, Guilin 541001; \\ ${ }^{2}$ Gamma Knife Center, The Second Hospital of Changchun, Changchun 130062; \\ Departments of ${ }^{3}$ Hepatobiliary Surgery and ${ }^{4}$ General Surgery, Affiliated Hospital \\ of Guilin Medical University, Guilin 541001, P.R. China
}

Received September 23, 2012; Accepted December 11, 2012

DOI: $10.3892 / 01.2012 .1084$

\begin{abstract}
Embelin is a small molecular inhibitor extracted from Myrsinaceae plants that specifically inhibits XIAP, affecting the proliferation and apoptosis of various types of tumor cells. In our previous studies, we have demonstrated that embelin is able to induce the apoptosis of MCF-7 breast cancer cells in a dose-dependent manner. However, its mechanism of action is not yet clear. The purpose of this study was to investigate the involvement of the mitochondrial pathway in embelin-induced apoptosis and the effect of embelin on the cell cycle. Different doses of embelin were added to MCF-7 breast cancer cells and it was found that embelin was able to induce apoptosis of MCF-7 breast cancer cells in a dose- and time-dependent manner. Flow cytometry analysis revealed that embelin caused changes in the MCF-7 cell mitochondrial membrane potential and blocked the cell cycle of MCF-7 cells in the G2/M phase. Moreover, embelin was demonstrated to promote mitochondrial release of cytochrome $\mathrm{C}$ via regulation of $\mathrm{Bax}$ and $\mathrm{Bcl}-2$, resulting in the activation of caspase- 3 and -9 , while no significant changes in the level of caspase- 8 were observed. The results have demonstrated that embelin-induced apoptosis of MCF-7 breast cancer cells involves the mitochondrial pathway.
\end{abstract}

\section{Introduction}

Breast cancer is a serious disease that threatens the health of individuals and is the most common malignant tumor in

Correspondence to: Dr Bo Tang, Department of Hepatobiliary Surgery, Affiliated Hospital of Guilin Medical University, No. 15, Lequn Road, Guilin 541001, P.R. China

E-mail: dytangbo@163.com

*Contributed equally

Key words: embelin, XIAP, breast cancer MCF-7 cell, apoptosis, mitochondria females. It is a major disease affecting females in particular, and its incidence is increasing annually (1-3). The key therapeutic approach for most breast cancer patients is to find an effective antitumor drug to assist surgical treatment.

Embelin is a small molecular inhibitor extracted from Myrsinaceae plants. It is a polyphenolic compound that inhibits XIAP by binding to the Smac binding site in the BIR3 domain of XIAP protein molecules (4-6). Previous studies have demonstrated that embelin has anti-inflammatory and anti-oxidative biological effects (7-10). It has been demonstrated that embelin has an extensive antitumor role and is able to restrain the growth of various tumor cells, including those of breast, colon, prostate and pancreatic cancer (11-14). However, the detailed mechanism of the antitumor activity of embelin remains unknown.

This study was designed to investigate the effect of embelin on cell apoptosis and the cell cycle of MCF-7 breast cancer cells in vitro, and to explore the embelin-induced cell apoptosis signaling pathway in MCF-7 cells. We have demonstrated that by regulating the $\mathrm{Bax}$ and $\mathrm{Bcl}-2$ proteins, embelin induces the release of cytochrome $\mathrm{C}$ and activates the caspase family to induce the apoptosis of breast cancer cells.

\section{Materials and methods}

Cell culture. MCF-7 breast cancer cells were purchased from the American Type Culture Collection (ATCC, Manassas, VA, USA). Following cell passage, cells were inoculated in RPMI-1640 culture medium (Gibco-BRL, Grand Island, NY, USA) containing $10 \%$ fetal calf serum (Hyclone Laboratories, Inc., Logan, UT, USA), $100 \mathrm{U} / \mathrm{ml}$ penicillin and $100 \mathrm{U} / \mathrm{ml}$ streptomycin. The cells were then cultured in an incubator containing $5 \% \mathrm{CO}_{2}$ and $95 \% \mathrm{O}_{2}$, at $37^{\circ} \mathrm{C}$.

Cell viability. MCF-7 cells in the logarithmic growth phase were collected and cultured in 96-well culture plates inoculated at a density of $1 \times 10^{5}$ cells $/ \mathrm{ml}$ for $24 \mathrm{~h}$. When the cells had grown to adherence, different doses of embelin were administered to 
various groups with 8 duplicate wells for each concentration. A negative control group without embelin was also created. All cells were incubated in $5 \% \mathrm{CO}_{2}$ for further culture for 24,48 and $72 \mathrm{~h}$ prior to the color reaction. Subsequently, MTT (5 mg/ $\mathrm{ml} ; 20 \mu \mathrm{l}$ ) was added to each well, and cells were cultured in $\mathrm{CO}_{2}$ at $37^{\circ} \mathrm{C}$ in an incubator for $4 \mathrm{~h}$. The culture solution was then diposed of. DMSO $(150 \mu \mathrm{l})$ was added to each well for room temperature oscillation for $10 \mathrm{~min}$, and the optical density (OD) values $\left(A_{570 \mathrm{~nm}}\right)$ of each well were measured with a microplate reader (Bio-Rad; Hercules, CA, USA)

Analysis of apoptosis via flow cytometry. A $0.25 \%$ trypsin digest was used to collect MCF-7 cells of all groups, and the cell density was adjusted to $1 \times 10^{6}$ cells $/ \mathrm{ml}$. Annexin V-FITC $(5 \mu \mathrm{l})$ and $5 \mathrm{ml}$ of propidium iodide (PI) were added for $30 \mathrm{~min}$ at $4^{\circ} \mathrm{C}$ to avoid light dyeing, prior to the flow cytometry analysis.

Analysis of cell cycle by flow cytometry. MCF-7 cells of all groups were digested and collected using $0.25 \%$ trypsin, and then washed with PBS solution. Cells were fixed at $4^{\circ} \mathrm{C}$ with $75 \%$ cold ethanol overnight and washed with PBS solution. The cell density was adjusted to $1 \times 10^{6}$ cells $/ \mathrm{ml}$ and the final volume was $100 \mu 1$. DNAStain comprehensive dye liquor (500 ml; Sigma, St. Louis, MO, USA) was added for storage at room temperature in a dark place for $30 \mathrm{~min}$ prior to testing with flow cytometry. The DNAStain contained RNase, PI and Triton X-100 at end concentrations of $50 \mathrm{mg} / \mathrm{l}, 100 \mathrm{mg} / \mathrm{l}$ and $1 \mathrm{ml} / 1$, respectively.

Flow cytometric analysis of mitochondrial membrane potential. The cell density was adjusted to $1 \times 10^{6}$ cells $/ \mathrm{ml}$ and JC-1 dye with an end concentration of $10 \mathrm{mg} / \mathrm{ml}$ was added. This was then mixed and cultured for $30 \mathrm{~min}$ at $37^{\circ} \mathrm{C}$ in the dark. Analysis with flow cytometry followed. FL1-H indicated a green fluorescence intensity and FL2-H was a red fluorescence intensity. Quantitative analysis was conducted using the CellQuest analysis software.

Western blot analysis. MCF-7 cells of all groups were collected using a trypsin digest and $2 \mathrm{ml}$ of lysis solution (50 mM Tris-HCl, $137 \mathrm{mM} \mathrm{NaCl}, 10 \%$ glycerin, $100 \mathrm{mM}$ sodium vanadate, $1 \mathrm{mM}$ PMSF, $10 \mathrm{mg} / \mathrm{ml}$ aprotinin, $10 \mathrm{mg} / \mathrm{ml}$ leupeptin, $1 \% \mathrm{NP}-40$ and $5 \mathrm{mM}$ cocktail; $\mathrm{pH}$ 7.4) was added for cell lysis to obtain the proteins. Following the BCA assay, proteins were loaded onto a gel and separated by SDS-PAGE. The proteins were then transferred to a PVDF membrane using a semi-dry method and sealed with $5 \%$ skimmed mild powder at $4^{\circ} \mathrm{C}$ overnight. The membrane was washed with Tris-buffered saline Tween-20 (TBST) and the first antibody was added at $37^{\circ} \mathrm{C}$ for hybridization for $1 \mathrm{~h}$, prior to bleaching with TBST. The second antibody was then added at $37^{\circ} \mathrm{C}$ for hybridization for $1 \mathrm{~h}$ prior to bleaching with TBST and a color reaction for $5 \mathrm{~min}$ with autoradiography. Quantity One software was used for OD value analysis and measurements.

Statistical analysis. The SPSS software, version 16.0 was used for assessing dependence and for variance analysis. Values are presented as mean \pm standard deviation. $\mathrm{P}<0.05$ was consid-

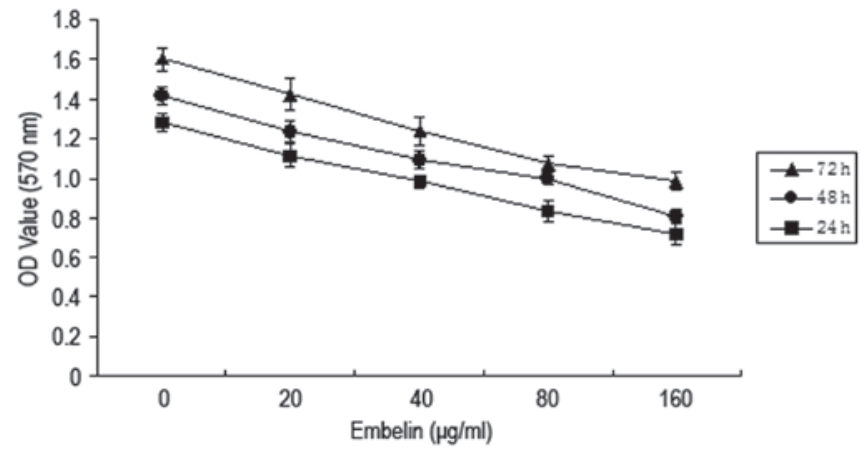

Figure 1. Embelin-induced inhibition of MCF-7 breast cancer cell growth Cell viability was examined with the MTT method following the addition of different concentrations of embelin $(0,20,40,80$ and $160 \mu \mathrm{g} / \mathrm{ml})$ to MCF-7 cells for 24, 48 and $72 \mathrm{~h}$. The results are representative of eight independent experiments. OD, optical density.

ered to indicate a statistically significant difference between groups.

\section{Results}

Embelin induces inhibition of MCF-7 breast cancer cell growth. Different concentrations of embelin (0, 20, 40, 80 and $160 \mu \mathrm{g} / \mathrm{ml}$ ) were added to MCF-7 breast cancer cells for 24, 48 and $72 \mathrm{~h}$. The MTT method was then employed to determine the cell activity (Fig. 1). The results demonstrated that $\mathrm{A}_{570}$ values of breast cancer MCF-7 cells gradually decreased when the concentration of embelin was increased, and the $\mathrm{A}_{570}$ value decreased most when the concentration of embelin was $80 \mu \mathrm{g} / \mathrm{ml}$. This indicates that embelin has an inhibitory effect on the growth of MCF-7 breast cancer cells.

Embelin induces apoptosis of MCF-7 breast cancer cells. MCF-7 breast cancer cells were treated with different concentrations of embelin for $48 \mathrm{~h}$ and flow cytometry was used to investigate the effect on the rate of apoptosis (Fig. 2). Our results demonstrated that, with an increase in the concentration of embelin, the rate of MCF-7 breast cancer cell apoptosis significantly increased in a dose-dependent manner.

Embelin induces apoptosis of MCF-7 breast cancer cells via the mitochondrial pathway. JC-1 coloration was used to examine the changes in the mitochondrial membrane potential. The results demonstrated a gradual decrease in the mitochondrial membrane potential along with an increase in the concentration of embelin. Additionally, the change in the mitochondrial membrane potential was observed prior to apoptosis (Fig. 3A). Western blot analysis was employed to examine the levels of $\mathrm{Bax}, \mathrm{Bcl}-2$ and cytochrome $\mathrm{C}$ inside the cytoplasm. It was revelaed that when the concentration of embelin was increased, the level of Bax protein gradually decreased, while the level of cytochrome $\mathrm{C}$ increased (Fig. 3B and C). Furthermore, the level of Bcl-2 protein was observed to increase when the concentration of embelin was increased. Our data demonstrated that embelin is able to change the mitochondrial membrane potential to promote a change in the levels of Bax and Bcl-2 as well as the release of cytochrome C, which results in the apoptosis of MCF-7 breast cancer cells. 
A





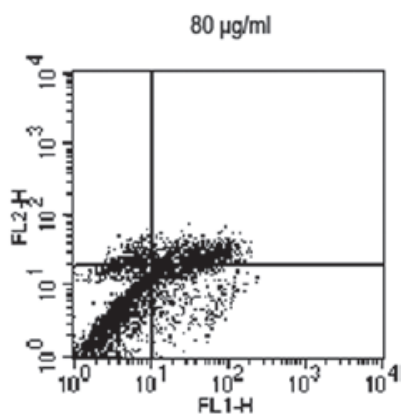

B

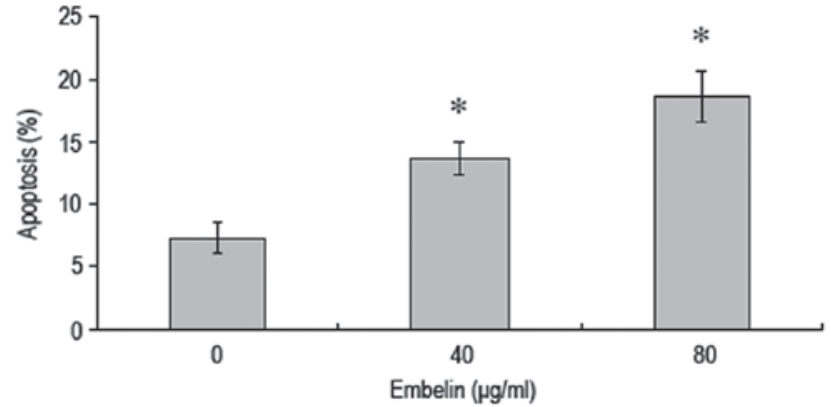

Figure 2. Embelin induced MCF-7 breast cancer cell apoptosis. (A) Annexin V/propidium iodide (PI) dye was used to determine the rate of apoptosis following treatment of MCF-7 cells with different concentrations of embelin ( 0,40 and $80 \mu \mathrm{g} / \mathrm{ml})$ for $48 \mathrm{~h}$. (B) The histogram shows the apopotosis rate (\%) of MCF-7 cells. " $\mathrm{P}<0.05$ vs. control. The data are representative of three independent experiments.

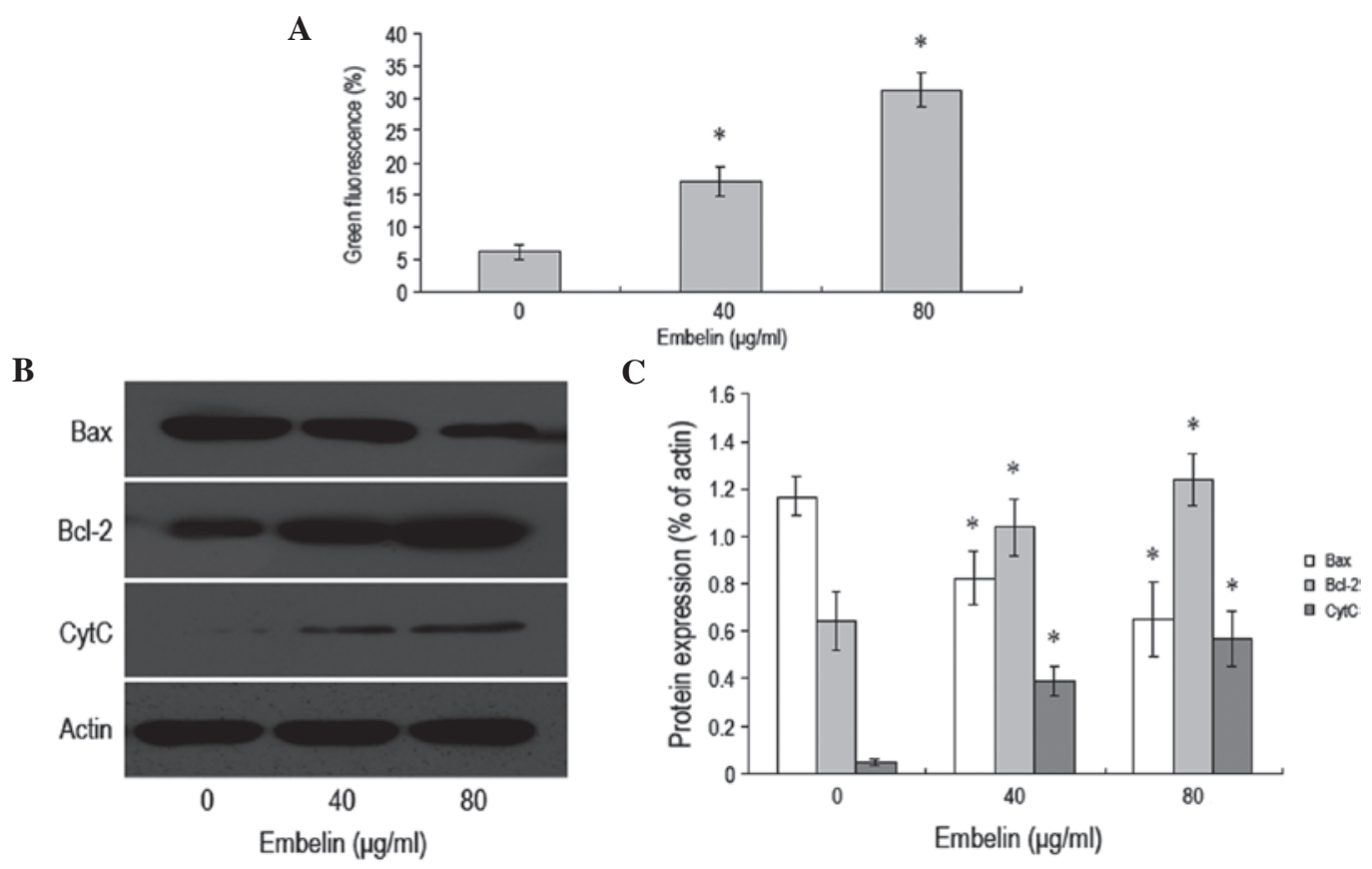

Figure 3. Embelin induced MCF-7 breast cancer cell apoptosis via the mitochondrial pathway, following treatment of MCF-7 cells with different concentrations of embelin $(0,40$ and $80 \mu \mathrm{g} / \mathrm{ml})$ for $48 \mathrm{~h}$. (A) JC-1 dye flow cytometry was used to analyze the change in the mitochondrial membrane potential. (B) Western blot analysis was used to determine the expression levels of Bax, Bcl-2 and cytochrome C proteins inside the cytoplasm. (C) The western blot analysis results were further analyzed using Gel-Pro Analyzer 4.0 software. ${ }^{*} \mathrm{P}<0.05$ vs. control. Results are representative of three independent experiments.

Effect of embelin on the expression levels of apoptosis-related proteins in MCF-7 breast cancer cells. In order to study the effect of embelin on the expression levels of MCF-7 breast cancer cell apoptosis-related proteins, different concentrations of embelin were administered to MCF-7 cells for $48 \mathrm{~h}$, and western blot analysis was conducted to investigate the expression levels of procaspase-3, -8 and -9 proteins (Fig. 4). It was found that following treatment with different concentrations of embelin, the expression levels of MCF-7 breast cancer cell procaspase- 3 and -9 proteins signficantly decreased, while no significant differences were observed in the expression level of procaspase- 8 protein. Our data demonstrated that embelin-induced MCF-7 apoptosis may occurr through the mitochondria-mediated caspase-3 and -9 pathways. 

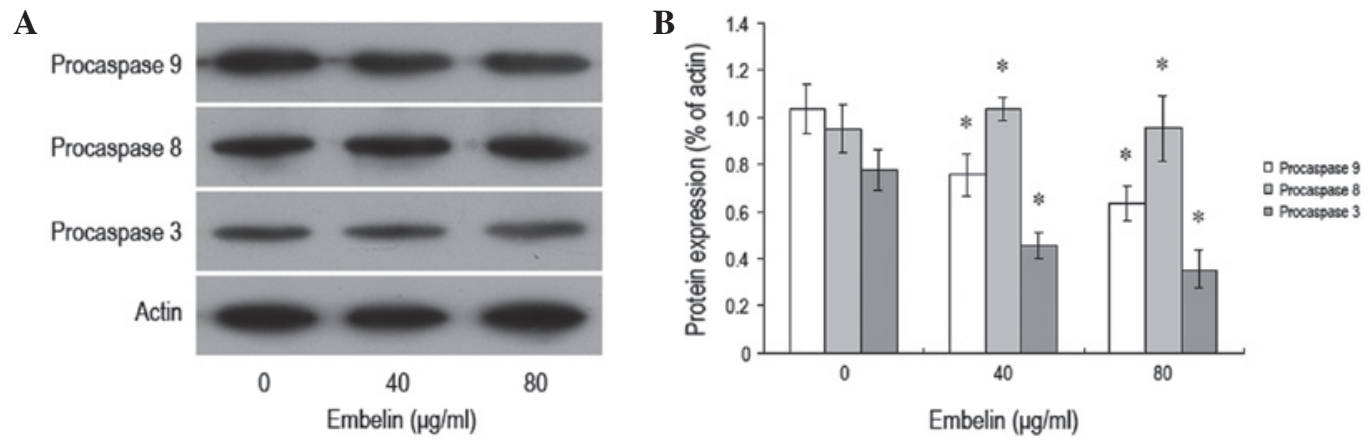

Figure 4. Effect of embelin on the expression levels of MCF-7 breast cancer cell apoptosis-related proteins, including procaspase-3, -8 and $-9,48 \mathrm{~h}$ following the treatment of MCF-7 breast cancer cells with different concentrations of embelin ( 0,40 and $80 \mu \mathrm{g} / \mathrm{ml})$. (A) Western blot analysis was used to analyze the expression of procaspase-3, -8 and -9 proteins. (B) The western blot analysis results were further analyzed using Gel-Pro Analyzer 4.0 software. ${ }^{*} \mathrm{P}<0.05$ vs. control. Results are representative of three independent experiments.

A
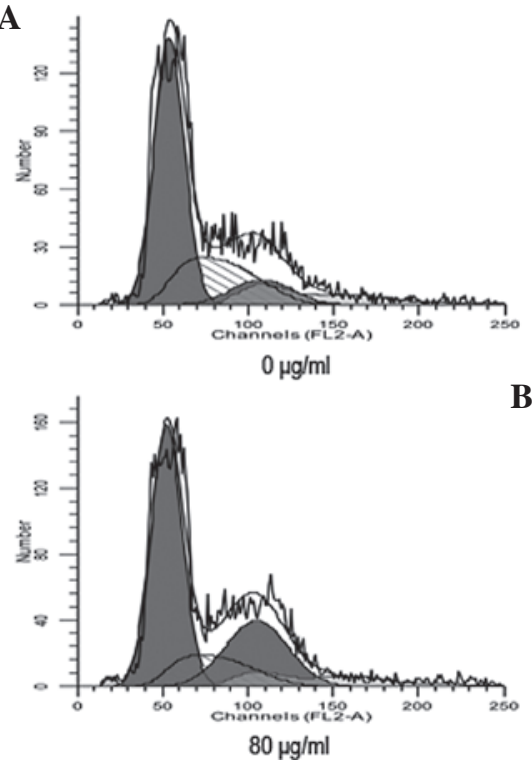

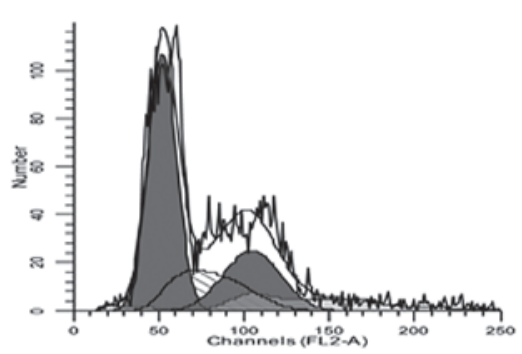

$40 \mu \mathrm{g} / \mathrm{ml}$



Figure. 5. Effect of embelin on the cell cycle of MCF-7 breast cancer cells, following treatment of the cells with different concentrations of embelin ( 0,40 and $80 \mu \mathrm{g} / \mathrm{ml}$ ) for $48 \mathrm{~h}$. (A) Flow cytometry was used to analyze the cell cycle. (B) The histogram shows the percentage of cells in G2/M phase of the cell cycle. ${ }^{*} \mathrm{P}<0.05$ vs. control. The data are representative of three independent experiments.

Embelin-induces MCF-7 breast cancer cell cycle blockade in $G 2 / M$ phase. Flow cytometry was conducted to investigate whether embelin affected the cell cycle of MCF-7 breast cells. The results revealed that $48 \mathrm{~h}$ following the addition of different concentrations of embelin to MCF-7 cells, a cell cycle blockade was observed in the G2/M phase compared with the control group (Fig. 5). This suggests that embelin is able to increase the percentage of MCF-7 cells in the $\mathrm{G} 2 / \mathrm{M}$ phase to decrease the proliferation of breast cancer cells.

\section{Discussion}

Kerr et al (15) first proposed the concept of apoptosis. Apoptosis is ubiquitous in the majority of tumor cells, and is important in the genesis and progression of tumors (16). Previous studies have demonstrated that antitumor drugs typically inhibit tumors by inducing apoptosis of sensitive tumor cells. Therefore, the intervention in apoptosis to treat tumors has become a new target in the search for antitumor drugs and a new development direction in present tumor pharmacology.
Breast cancer is a potentially life-threatening malignant tumor; it is important to study the disease to find effective antitumor drugs. Antitumor drugs that originate from plants have benefits including an extensive variety, low toxicity and few side-effects and adverse reactions. Therefore, highly effective antitumor drugs from plants are being explored. Embelin is a small molecular inhibitor with specific inhibition of XIAP that affects the proliferation and apoptosis of various tumor cells. Certain studies have demonstrated that embelin inhibits the proliferation of various tumor cells; significant effects have been observed in breast cancer and other solid tumor cells (17). The results of the present study are concordant with these findings. We demonstrated that when breast cancer cells had been treated with different concentrations of embelin for $48 \mathrm{~h}$, the rate of cell apoptosis increased in a dose-dependent manner, indicating that embelin is able to induce breast cancer cell apoptosis as opposed to directly causing cell death. Moreover, embelin has the potent effect of restraining the cell cycle transition of breast cancer cells to blockade the cell cycle in G2/M phase, therefore altering the progression of the cell cycle to induce apoptosis. 
There are various signaling pathways of apoptosis within an organism, of which the mitochondrial pathway is one of the most important. Bcl-2 family proteins are key regulatory factors of the mitochondrial pathway (18-20). We demonstrated that that when breast cancer cells had been treated with different doses of embelin for $48 \mathrm{~h}$, Bax and Bcl-2 migrated, the mitochondrial membrane potential increase expression of Bax, while Bcl-2 expression decreased and cytochrome $\mathrm{C}$ was released. These results indicated that the induction of breast cancer cell apoptosis by embelin was closely associated with the mitochondrial pathway. As demonstrated in previous studies, with the stimulation of pro-apoptosis factors, the Bax protein migrated from the cytoplasm to the outer mitochondrial membrane, changing the permeability of the outer mitochondrial membrane to promote the mitochondrial release of cytochrome C (21). Moreover, $\mathrm{Bcl}-2$ protein is able to stabilize the mitochondrial permeability transition pore (mPTP) and maintain the normal functioning of the pore. In the present study, we demonstrated that with embelin treatment, the Bcl-2 protein level inside the cytoplasm gradually decreased while the release of cytochrome $\mathrm{C}$ increased in a stepwise manner. This indicates that embelin induces the activity of Bcl-2, causing the mPTP to open irreversibly, which further changes the permeability of the mitochondrial membrane and promotes the release of cytochrome $\mathrm{C}$. The combination of these factors results in apoptosis.

The caspase family activates apoptosis-related protease when apoptosis occurs $(22,23)$, and a series of subsequent biological effects occur in turn. Therefore, activation of the caspase family is important in the process of apoptosis. We analyzed the changes in procaspase-3, -8 and -9 proteins following treatment of breast cancer cells with embelin. A significant decrease in procaspase- 3 and -9 expression was observed when breast cancer apoptosis occured, but no changes in the level of procaspase 8 expression were identified. The effect of releasing cytochrome $\mathrm{C}$ from the mitochondria to activate caspase- 3 and -9 is an important step of the apoptotic pathway $(24,25)$. These results suggest that embelin-induced apoptosis of breast cancer cells is realized via the endogenous mitochondrial pathway as opposed to via the exogenous death receptor pathway.

In summary, our study has demonstrated that embelin releases cytochrome $\mathrm{C}$ and activates the caspase family to result in the induction of breast cancer apoptosis through regulation of the action of the Bcl-2/Bax family in the mitochondrial pathway. Embelin may offer important contributions for the development of a novel drug to prevent and cure breast cancer in the future.

\section{References}

1. McPherson K, Steel CM and Dixon JM: ABC of breast diseases. Breast cancer-epidemiology, risk factors, and genetics. BMJ 321: 624-628, 2000.

2. Benson JR and Jatoi I: The global breast cancer burden. Future Oncol 8: 697-702, 2012.

3. Anderson WF, Katki HA and Rosenberg PS: Incidence of breast cancer in the United States: current and future trends. J Natl Cancer Inst 103: 1397-1402, 2011.

4. Reuter S, Prasad S, Phromnoi K, Kannappan R, Yadav VR and Aggarwal BB: Embelin suppresses osteoclastogenesis induced by receptor activator of NF- $\kappa$ B ligand and tumor cells in vitro through inhibition of the NF- $\mathrm{BB}$ cell signaling pathway. $\mathrm{Mo}$ Cancer Res 8: 1425-1436, 2010.

5. Hu R, Zhu K, Li Y, Yao K, Zhang R, Wang H, Yang W and Liu Z: Embelin induces apoptosis through down-regulation of XIAP in human leukemia cells. Med Oncol 28: 1584-1588, 2011.
6. Nikolovska-Coleska Z, Xu L, Hu Z, Tomita Y, Li P, Roller PP, Wang R, Fang X, Guo R, Zhang M, Lippman ME, Yang D and Wang S: Discovery of embelin as a cell-permeable, small-molecular weight inhibitor of XIAP through structure-based computational screening of a traditional herbal medicine three-dimensional structure database. J Med Chem 47: 2430-2440, 2004.

7. Joshi R, Kamat JP and Mukherjee T: Free radical scavenging reactions and antioxidant activity of embelin: biochemical and pulse radiolytic studies. Chem Biol Interact 167: 125-134, 2007.

8. Sreepriya M and Bali G: Effects of administration of Embelin and Curcumin on lipid peroxidation, hepatic glutathione antioxidant defense and hematopoietic system during N-nitrosodiethylamine/ Phenobarbital-induced hepatocarcinogenesis in Wistar rats. Mol Cell Biochem 284: 49-55, 2006.

9. Mahendran S, Badami S, Ravi S, Thippeswamy BS and Veerapur VP: Synthesis and evaluation of analgesic and antiinflammatory activities of most active free radical scavenging derivatives of embelin-A structure-activity relationship. Chem Pharm Bull 59: 913-919, 2011.

10. Thippeswamy BS, Mahendran S, Biradar MI, Raj P, Srivastava K, Badami S and Veerapur VP: Protective effect of embelin against acetic acid induced ulcerative colitis in rats. Eur J Pharmacol 654: 100-105, 2011.

11. Danquah M, Li F, Duke CB III, Miller DD and Mahato RI: Micellar delivery of bicalutamide and embelin for treating prostate cancer. Pharm Res 26: 2081-2092, 2009.

12. Dai Y, Qiao L, Chan KW, Yang M, Ye J, Ma J,Zou B, Gu Q, Wang J, Pang R, Lan HY and Wong BC: Peroxisome proliferator-activated receptor-gamma contributes to the inhibitory effects of Embelin on colon carcinogenesis. Cancer Res 69: 4776-4783, 2009.

13. Aird KM, Ding X, Baras A, Wei J, Morse MA, Clay T, Lyerly HK and Devi GR: Trastuzumab signaling in ErbB2-overexpressing inflammatory breast cancer correlates with X-linked inhibitor of apoptosis protein expression. Mol Cancer Ther 7: 38-47, 2008.

14. Mori T, Doi R, Kida A, Nagai K, Kami K, Ito D, Toyoda E, Kawaguchi Y and Uemoto S: Effect of the XIAP inhibitor Embelin on TRAIL-induced apoptosis of pancreatic cancer cells. J Surg Res 142: 281-286, 2007.

15. Kerr JF, Wyllie AH and Currie AR: Apoptosis: a basic biological phenomenon with wide-ranging implications in tissue kinetics. Br J Cancer 26: 239-257, 1972.

16. Chiarugi $P$ and Giannoni E: Anoikis: a necessary death program for anchorage-dependent cells. Biochem Pharmacol 76: 1352-1364, 2008.

17. Allensworth JL, Aird KM, Aldrich AJ, Batinic-Haberle I and Devi GR: XIAP inhibition and generation of reactive oxygen species enhances TRAIL sensitivity in inflammatory breast cancer cells. Mol Cancer Ther 11: 1518-1527, 2012.

18. Tang B, Zhang Y, Liang R, Yuan P, Du J, Wang H and Wang L: Activation of the $\delta$-opioid receptor inhibits serum deprivationinduced apoptosis of human liver cells via the activation of PKC and the mitochondrial pathway. Int J Mol Med 28: 1077-1085, 2011.

19. Mattson MP and Kroemer G: Mitochondria in cell death: novel targets for neuroprotection and cardioprotection. Trends Mol Med 9: 196-205, 2003

20. Burlacu A: Regulation of apoptosis by Bcl-2 family proteins. J Cell Mol Med 7: 249-257, 2003.

21. Saito M, Korsmeyer SJ and Schlesinger PH: BAX-dependent transport of cytochrome c reconstituted in pure liposomes. Nat Cell Biol 2: 553-555, 2000.

22. Nicholson DW, Ali A, Thornberry NA, Vaillancourt JP, Ding CK, Gallant M, Gareau Y, Griffin PR, Labelle M and Lazebnik YA: Identification and inhibition of the ICE/CED-3 protease necessary for mammalian apoptosis. Nature 376: 37-43, 1995.

23. Hyman BT and Yuan J: Apoptotic and non-apoptotic roles of caspases in neuronal physiology and pathophysiology. Nat Rev Neurosci 13: 395-406, 2012.

24. Riedl SJ and Shi Y: Molecular mechanisms of caspase regulation during apoptosis. Nat Rev Mol Cell Biol 5: 897-907, 2004.

25. Shi LG, Zhang GP and Jin HM: Inhibition of microvascular endothelial cell apoptosis by angiopoietin-1 and the involvement of cytochrome C. Chin Med J (Engl) 119: 725-730, 2006. 